International Journal of Business Management and Economic Review

Vol. 4, No. 03; 2021

ISSN: 2581-4664

\title{
THE ROLE OF WORK STRESS IN MEDIATING THE EFFECT OF PERFORMANCE PRESSURE AND WORKLOAD ON EMPLOYEE PERFORMANCE IN UNIVERSITAS MUHAMMADIYAH ACEH
}

\author{
*Reza Juli Amri, Sorayanti Utami, Syafruddin Chan \\ Management Department, Universitas Syiah Kuala, Indonesia \\ http://doi.org/10.35409/IJBMER.2021.3259
}

\begin{abstract}
Employee performance contains work results in quality and quantity achieved by an employee in carrying out his duties according to his responsibilities. The purpose of this study was to see the effect of Performance Pressure and Workload on Work Stress and its impact simultaneously on employee performance. The population in this study was all employees who worked at the Universitas Muhammadiyah Aceh, as many as 328 people. The sample was taken with a stratified random sampling method on 140 people. The result shows that Performance pressure does not affect employee performance, Workload affects employee performance, Performance pressure affects the work stress, Workload affects work stress, Work stress affects employee performance, Work stress mediates the effect of performance pressure on employee performance, and Work stress mediates the effect of workload on employee performance. The role of work stress in mediating the effect of performance pressure on employee performance is as a full mediation, while in mediating the effect of performance pressure on employee performance the work stress acts as a partial mediation. These results indicate that increasing performance pressure is necessary so that it can increase adjustment to work stress and have an impact on improving employee performance. Performance pressure cannot directly affect employee performance but must go through work stress as a mediator. On the other hand, workloads can affect employee performance either directly or through work stress as a mediator. Increased adjustments to workloads will increase adjustments to work stress and have an impact on improving employee performance. For future researchers, it is advisable to develop this tested model by adding variables such as talent management and human capital, which are of course closely related to the discussion and development of performance models.
\end{abstract}

Keyword: Performance Pressure, Workload, Work Stress, Employee Performance.

\section{INTRODUCTION}

Universitas Muhammadiyah Aceh is one of the private higher education institutions in the city of Banda Aceh, Indonesia, with one of its missions, namely to provide education, research, and community service that are superior, professional, and Islamic. To achieve this goal, employees must be able to cope with the existing performance pressures. The opinion that there is a relationship between performance pressure and employee performance has at least been 


\section{International Journal of Business Management and Economic Review}

Vol. 4, No. 03; 2021

ISSN: 2581-4664

expressed by (Eisenberger \& Aselage, 2009). In addition to performance pressure and work stress, workload also affects employee performance. This opinion was conveyed by (Dasgupta, 2013) in his research which revealed a significant effect of workload and work motivation on employee performance.

In contrast to previous studies which examined the role of external performance pressure (Decramer, Smolders, Vanderstraeten, Christiaens, \& Desmidt, 2012), In this study the authors focused on internal performance pressure which is no less heavy for employees to solve to pursue better work performance. This has not been done by many previous researchers. This aspect is important to study because of its very strategic role in supporting the improvement of overall employee performance. Therefore, the concept of internal performance pressure is what the writer adopts as one of the factors that affect employee performance either directly or through work stress.

\section{LITERATURE REVIEW Employee Performance}

The definition of performance is the level of achievement of the program or policies to attain the objectives, of the organization poured (Decramer, Smolders, Vanderstraeten, \& Christiaens, 2012). Performance is a description of the level the achievement of an activity program or policy in reaching objectives, (Sasra, Lubis, \& Chan, 2015).

Performance appraisal is an effort made by the leader to evaluate the work of his subordinates. Job appraisal is a process taken by leaders to get to know whether an employee is doing his job according to his duties and responsibilities. (Fachreza, Musnadi, \& Shabri, 2018).

\section{Work stress}

Work stress is external instructions that hit a person, objects in the environment, or a stimulus that is objectively dangerous. Stress can also be defined as pressure, disturbance, or unpleasant disturbance that comes from outside a person.(Önday, 2016). So it can be said that that work stress arises because of demands and the reaction of each individual in dealing with those that affect themselvescan be different from one to another.

\section{Performance Pressure}

Performance pressure is usually defined in three ways, namely "as environmental stimulation namely the power inflicted on individuals, as an individual's physical or psychological response to the strength of the environment, and as an interaction between the two events(Robbins \& Coulter, 2016). Pressure in this case is a condition of tension that affects one's emotions, thought processes, and condition. Whether the tension is positive or negative depends on the level of tolerance of the individual concerned. People give different reactions to situations that from the outside seem to cause the same physical and psychological demands, (Ahmad et al., 2018).

\section{Workload}

Workload also reflects the number of tasks assigned to someone that has to be finished by him or his team during the period agreed by both parties. The workload is activities that must be completed by a worker within a certain period which is beyond his ability to finish those tasks. When they can complete those assigned tasks, then this does not become a workload. However, 
International Journal of Business Management and Economic Review

Vol. 4, No. 03; 2021

ISSN: 2581-4664

if the worker is unsuccessful then these tasks and activities become a workload.(Shah et al., 2011).

\section{Research paradigm}

The research framework that connects all variables involved in this study can be drawn on the following figure.

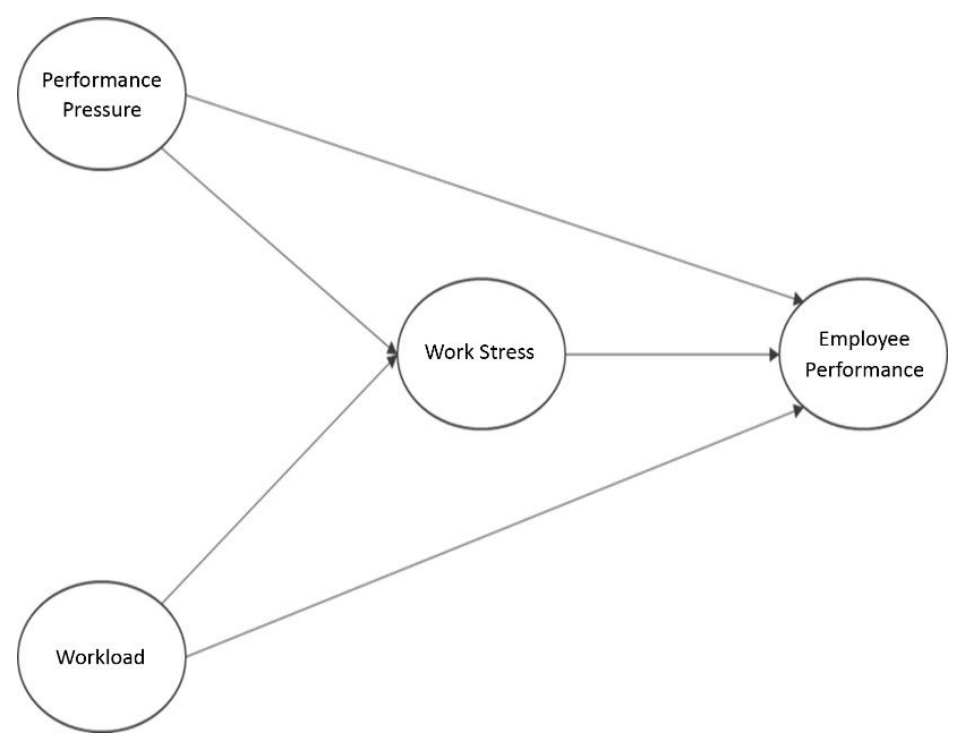

Figure 1 Research Framework

\section{Hypothesis}

Based on the phenomena and from the theoretical foundations that have been stated previously, several research hypotheses can be stated as follows:

$\mathrm{H} 1$ :Performance pressure affects employee performance

H2 : Workload affects employee performance

$\mathrm{H} 3$ : Performance pressure affects the work stress

H4 : Workload affects work stress

H5 : Work stressemployee performance

H6 : Work stressmediates the effect of performance pressure on employee performance

$\mathrm{H} 7$ : Work stressmediates the effect of workload on employee performance

\section{METHOD}

\section{Location and Object of Research}

This research was conducted at the Universitas Muhammadiyah Aceh. The object of this research was all employees at the Universitas Muhammadiyah Aceh. The variables were employee performance, work stress, workload, and performance pressure.

\section{Sampling}

The population was 328 employees who work at the Universitas Muhammadiyah Aceh. The stratified random sampling technique was used for sampling. The sample in this study was 140 


\section{International Journal of Business Management and Economic Review}

Vol. 4, No. 03; 2021

ISSN: 2581-4664

people.

\section{Data analysis method}

Data were processed using Structural Equation Modeling (SEM). The use of SEMwas necessary, because of the multivariate element in the research model. Hypothesis testing used CR criteria and probability figures for the standard error at the level of $5 \%$.

\section{RESULT AND DISCUSSION}

\section{Loading Factor with measurement test}

Testing the validity of loading factors can be seen in the following figure and table:

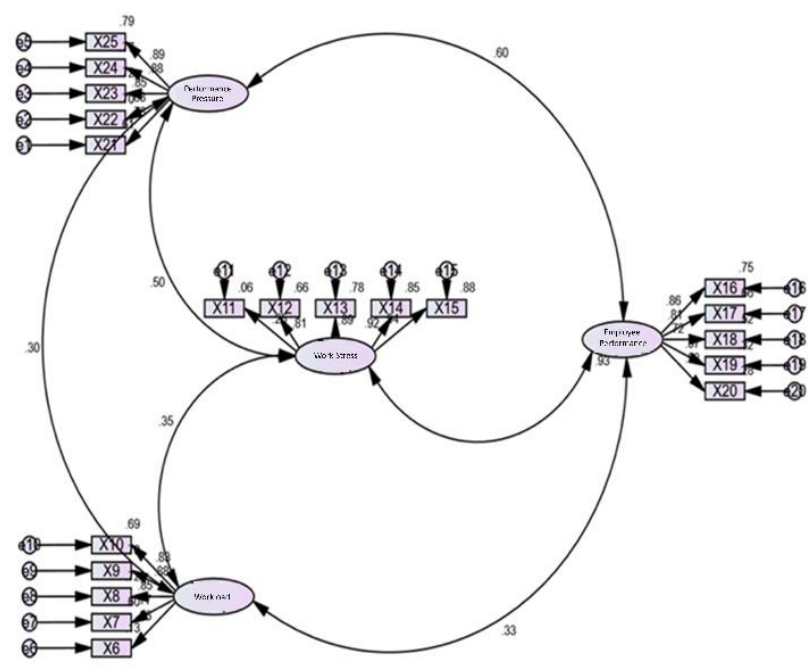

Figure 2 Loading Factor

Because it contained multi indicators, it was necessary to confirm the indicators quoted from previous studies, whether they were still relevant to the research model built in this study. For indicators that did not meet the requirements becausethey had a relatively small coefficient value, were eliminated from the model.

Table 1Loading Factor

\begin{tabular}{|l|l|l|l|l|}
\hline No. & Indicator & & Variable & Estimate \\
\hline 1 & X21 & K--- & Work_Stress & .781 \\
\hline 2 & X22 & K--- & Work_Stress & .835 \\
\hline 3 & X23 & K--- & Work_Stress & .850 \\
\hline 4 & X24 & <--- & Work_Stress & .875 \\
\hline 5 & X25 & <--- & Work_Stress & .887 \\
\hline 6 & X7 & K--- & Performance_Pressure & .766 \\
\hline 7 & X8 & <--- & Performance_Pressure & .851 \\
\hline 8 & X9 & K--- & Performance_Pressure & .889 \\
\hline
\end{tabular}


Vol. 4, No. 03; 2021

ISSN: 2581-4664

\begin{tabular}{|l|l|l|l|l|l|}
\hline \hline No. & Indicator & & Variable & Estimate \\
\hline 9 & X10 & $<---$ & Performance_Pressure & .829 \\
\hline 10 & X12 & $<---$ & Workload & .807 \\
\hline 11 & X13 & $<---$ & Workload & .883 \\
\hline 12 & X14 & $<---$ & Workload & .922 \\
\hline 13 & X15 & $<---$ & Workload & .940 \\
\hline 14 & X16 & $<---$ & Employee_Performance & .865 \\
\hline 15 & X17 & $<---$ & Employee_Performance & .814 \\
\hline 16 & X18 & $<---$ & Employee_Performance & .719 \\
\hline 17 & $\mathrm{X} 19$ & $<---$ & Employee_Performance & .566 \\
\hline 18 & X20 & $<---$ & Employee_Performance & .529 \\
\hline
\end{tabular}

Table 1 shows the loading factor of all the indicators in the model and has met the requirements for further processing because it has a loading factor value $>0.5$.

Table 2. The goodness of Fit Criteria

\begin{tabular}{|l|l|l|l|}
\hline Size Index Criteria & Cut-off Value & Analysis Result & Model Evaluation \\
\hline Chi-Square & Small expected & 241.171 & Good \\
\hline CMIN / DF & CMIN / DF $<2$ & 1977 & Good \\
\hline GFI & $\geq 0.90$ & 0.883 & Good \\
\hline AGFI & $\geq 0.90$ & 0.836 & Good \\
\hline RMSEA & $<0.08$ & 0.070 & Good \\
\hline
\end{tabular}

\section{Structural Analysis for Direct Hypothesis testing}

The results of the data processed by using SEM have produced the information needed to answer the previously built hypothesis, whether it is proven or not. 


\section{International Journal of Business Management and Economic Review}

Vol. 4, No. 03; 2021

ISSN: 2581-4664

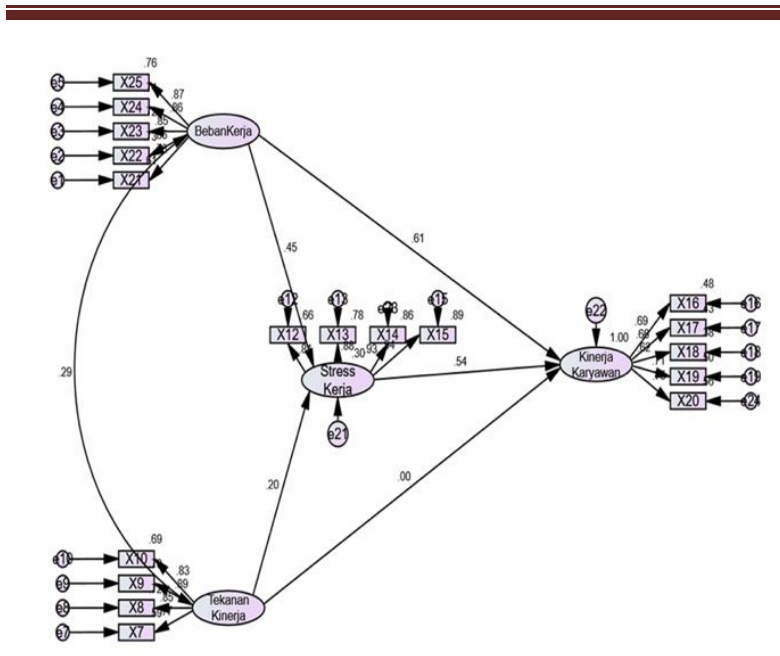

Figure 3. Structural Equation Model

Based on Figure 3, it explains the influence of each variable, namely Performance Pressure, Workload, Work Stress, and Employee Performance.

\section{Table 3. Direct Hypothesis Result}

\begin{tabular}{|c|l|l|l|l|}
\hline No. & Hypothesis Results & $\begin{array}{l}\text { CR Cut off }> \\
\mathbf{1 . 9 6}\end{array}$ & $\begin{array}{l}\text { P-Value } \\
\text { Cut off }<\mathbf{0 . 0 5}\end{array}$ & Beta \\
\hline H1 & $\begin{array}{l}\text { There is no influence of performance } \\
\text { pressure on employee performance }\end{array}$ & -0.068 & 0.946 & 0.003 \\
\hline H2 & $\begin{array}{l}\text { There is an Influence of Workload on } \\
\text { Employee Performance }\end{array}$ & 11.540 & 0.000 & 0.614 \\
\hline H3 & $\begin{array}{l}\text { There is an Influence of Performance } \\
\text { Pressure on Work Stress }\end{array}$ & 2.842 & 0.004 & 0.201 \\
\hline H4 & $\begin{array}{l}\text { There is an Influence of Workload on } \\
\text { Work Stress }\end{array}$ & 6.186 & 0,000 & 0.454 \\
\hline H5 & $\begin{array}{l}\text { There is an Influence of Work Stress on } \\
\text { Employee Performance }\end{array}$ & 11.540 & 0.000 & 0.536 \\
\hline
\end{tabular}

It can be seen from the 5 direct hypotheses that there is 1 (one) insignificant hypothesis, namely the Effect of Performance Pressure on Employee Performance because it has a CR value of 0.068 and a p-value of 0.946 which does not meet the requirement of the hypothesis condition accepted. In other words, only the workload variable as an exogenous variable has an influence on employee performance of the Universitas Muhammadiyah Aceh.

\section{Indirect Influence}

The conclusion of the indirect hypothesis, namely the effect of Performance Pressure and Workload on Employee Performance through Work Stress, shown in Table 4 below: 
International Journal of Business Management and Economic Review

Vol. 4, No. 03; 2021

ISSN: 2581-4664

Table 4. Indirect Hypothesis Result

\begin{tabular}{|l|l|l|l|l|l|}
\hline $\begin{array}{l}\text { No } \\
.\end{array}$ & Indirect Hypothesis & $\begin{array}{l}\text { P-Value } \\
<0.05\end{array}$ & Beta & $\begin{array}{l}\text { Informati } \\
\text { on }\end{array}$ & $\begin{array}{l}\text { Role } \\
\text { Mediation }\end{array}$ \\
\hline H6 & $\begin{array}{l}\text { Work stress mediates the effect of } \\
\text { work pressure on employee } \\
\text { performance }\end{array}$ & 0.043 & $\begin{array}{l}0.10 \\
7\end{array}$ & Received & Full Mediation \\
\hline H7 & $\begin{array}{l}\text { Work stress mediates the effect of } \\
\text { Workload on employee performance }\end{array}$ & 0.000 & $\begin{array}{l}0.24 \\
3\end{array}$ & Received & Partial Mediation \\
\hline
\end{tabular}

Meanwhile, if we look at the indirect effect of the two hypotheses tested, the role of work stress in mediating the effect of workload on employee performance is more dominant than the role of performance pressure on employee performance at the Universitas Muhammadiyah Aceh. The role of work stress in mediating the effect of performance pressure on employee performance is as a full mediation, while in mediating the effect of performance pressure on employee performance the work stress acts as a partial mediation.

\section{CONCLUSION}

The result shows that Performance pressure does not affect employee performance, Workload affects employee performance, Performance pressure affects the work stress, Workload affects work stress, Work stress affects employee performance, Work stress mediates the effect of performance pressure on employee performance, and Work stress mediates the effect of workload on employee performance. The role of work stress in mediating the effect of performance pressure on employee performance is as a full mediation, while in mediating the effect of performance pressure on employee performance the work stress acts as a partial mediation. These results indicate that increasing performance pressure is necessary so that it can increase adjustment to work stress and have an impact on improving employee performance. Performance pressure cannot directly affect employee performance but must go through work stress as a mediator. On the other hand, workloads can affect employee performance either directly or through work stress as a mediator. Increased adjustments to workloads will increase adjustments to work stress and have an impact on improving employee performance. For future researchers, it is advisable to develop this tested model by adding variables such as talent management and human capital, which are of course closely related to the discussion and development of performance models.

\section{REFERENCES}

Ahmad, E. H., Maidin, A., Abdullah, T., Naiem, F., Buraerah, S., Handayanif, R., \& Prihantono. (2018). Relationship of Work Stress to the Performance of Intensive Care Unit Nurses in Makassar. American Journal of Public Health Research, 6(1), 18-20. https://doi.org/10.12691/ajphr-6-1-4

Dasgupta, P. R. (2013). Volatility of workload on employee performance and significance of motivation: IT sector. Science Journal of Business and Management, 1(1), 1-7. 


\section{International Journal of Business Management and Economic Review}

Vol. 4, No. 03; 2021

ISSN: 2581-4664

https://doi.org/10.11648/j.sjbm.20130101.11

Decramer, A., Smolders, C., Vanderstraeten, A., \& Christiaens, J. (2012). The Impact of Institutional Pressures on Employee Performance Management Systems in Higher Education in the Low Countries. British Journal of Management, 23(S1), S88-S103. https://doi.org/10.1111/j.1467-8551.2012.00820.x

Decramer, A., Smolders, C., Vanderstraeten, A., Christiaens, J., \& Desmidt, S. (2012). External pressures affecting the adoption of employee performance management in higher education institutions. Personnel Review, 41(6), 686-704. https://doi.org/https://doi.org/10.1108/00483481211263593

Eisenberger, R., \& Aselage, J. (2009). Incremental effects of reward on experienced performance pressure: positive outcomes for intrinsic interest and creativity. Journal of Organizational Behavior, 30(1), 95-117. https://doi.org/https://doi.org/10.1002/job.543

Fachreza, Musnadi, S., \& Shabri, M. (2018). Pengaruh Motivasi Kerja, Lingkungan Kerja, dan Budaya Organisasi Terhadap Kinerja Karyawan dan Dampaknya Pada Kinerja Bank Aceh Syariah Di Kota Banda Aceh. Jurnal Magister Manajemen, 2(1), 115-122.

Önday, Ö. (2016). Theories of Organizations and Environments: From Organizations and System Concept of Katz \& Kahn to Corporations and Industries of Carroll \& Hannan. Elixir Organizational Behaviour, 92, 39030-39035.

Robbins, S. P., \& Coulter, M. (2016). Manajemen (ed. 13). Jakarta: Erlangga.

Sasra, R. Y., Lubis, A. R., \& Chan, S. (2015). Pengaruh kompetensi, pendidikan dan pelatihan serta penempatan pegawai terhadap pengembangan karir dan dampaknya terhadap kinerja pegawai Sekretariat Daerah Provinsi Aceh. Jurnal Manajemen Pascasarjana Universitas Syiah, 4(2), 237-247.

Shah, S. S. H., Jaffari, A. R., Aziz, J., Ejaz, W., Ul-Haq, I., \& Raza, S. N. (2011). Workload and Performance of Employees. Interdisciplinary Journal of Contemporary Research in Business, 3(5), 256-267. Retrieved from https://journal-archieves8.webs.com/256-267.pdf 